\title{
An IS1-like element is responsible for high-level synthesis of extended- spectrum $\beta$-lactamase TEM-6 in Enterobacteriaceae
}

\author{
Sylvie Goussard, ${ }^{1}$ Wladimir Sougakoff,${ }^{1} \dagger$ Claude Mabilat, ${ }^{1} \ddagger$ Adolf Bauernfeind ${ }^{2}$ and \\ PATrice Courvalin ${ }^{*}$ \\ ${ }^{1}$ Unité des Agents Antibactériens, CNRS UA 271, Institut Pasteur, 28 rue du Dr. Roux, 75724 Paris Cedex 15, France \\ ${ }^{2}$ Max von Pettenkofer Institute, University of Munich, Pettenkoferstr. $9 a, D-8000$ München 2, \\ Federal Republic of Germany
}

(Received 24 May 1991; revised 20 August 1991; accepted 30 August 1991)

\begin{abstract}
Resistance of Escherichia coli strain HB251 to the newer $\beta$-lactam antibiotics, in particular ceftazidime and aztreonam, results from production of the extended-spectrum $\beta$-lactamase TEM-6. The corresponding structural gene, blaT-6, and its promoter region were amplified by the polymerase chain reaction. Analysis of the sequence of the amplification product showed that blaT-6 differed by two nucleotide substitutions from blaT-1, the gene encoding TEM-1 penicillinase in plasmid pBR322. The mutations led to the substitution of a lysine for a glutamic acid at position 102 and of a histidine for an arginine at position 162 of the unprocessed TEM-1 protein. The presence of a 116 bp DNA insert upstream from blaT-6 resulted in the creation of hybrid promoter $P_{6}$ in which the -10 region was that of TEM-1 promoter $P_{3}$ whereas the -35 canonical sequence TTGACA was provided by the right end of the insert. $P_{6}$ was found to be 10 times more active than $P_{3}$ and to confer higher levels of antibiotic resistance upon the host. Analysis of the sequence of the insert indicated that the $116 \mathrm{bp}$ fragment is related to insertion sequence IS1 but differs from it by three internal deletions that removed regions encoding the transposase. The distribution of the IS1-like element in clinical isolates of Enterobacteriaceae was studied by the polymerase chain reaction and by DNA-DNA hybridization. The element appeared to be widespread and was detected in strains producing TEM-6 or other TEM variants.
\end{abstract}

\section{Introduction}

$\beta$-Lactamases catalyse hydrolysis of the $\beta$-lactam ring in penicillins and cephalosporins. Among Gram-negative bacteria, plasmid-encoded penicillinases TEM-1 and TEM-2 are the most prevalent $\beta$-lactamases (Medeiros, 1989). These enzymes hydrolyse penicillins and the socalled first-generation cephalosporins but not the novel broad-spectrum second- and third-generation cephalosporins, such as cefotaxime and ceftazidime. Plasmid-

* Author for correspondence. e-mail address Earn/Bitnet: COURVAL@FRPSTR01.

† Present address: Department PF/ID, F. Hoffmann-La Roche \& Co., CH-4002 Basle, Switzerland.

$\ddagger$ Present address: Laboratoire bioMérieux, Ecole Normale Supérieure, 46 allée d'Italie, 69634 Lyon Cedex 07, France.

Abbreviations: CAT, chloramphenicol acetyltransferase; $\mathrm{IC}_{99}, 99 \%$ inhibitory concentration.

The nucelotide sequence data reported in this paper have been submitted to EMBL and have been assigned the accession number X57972. mediated resistance to cefotaxime and other recently developed cephalosporins was first described in 1983 in Serratia marcescens, Klebsiella pneumoniae and $K$. ozaenae (Knothe et al., 1983). Kliebe et al. (1985) showed that resistance was due to production of a new $\beta$ lactamase, SHV-2, that differed by a single mutation from the SHV-1 penicillinase commonly found in Klebsiella spp. (Barthélémy et al., 1988). More recently, other extended-spectrum plasmid-mediated $\beta$-lactamases that are variants of TEM-type penicillinases have been detected in strains highly resistant to thirdgeneration cephalosporins (for a review, see Philippon $\boldsymbol{e t}$ al., 1989). Enzymes TEM-3 and TEM-4 are characterized by similar levels of activity against cefotaxime and ceftazidime (Paul et al., 1989; Sirot et al., 1987) whereas TEM-5, $-6,-7$ and -9 were found in strains that are preferentially resistant to ceftazidime and aztreonam (Bauernfeind \& Hörl, 1987; Collatz et al., 1989; Petit et al., 1988; Spencer et al., 1987). With the exception of TEM-6, all these variants have been characterized at the molecular level. They differ from TEM-1 or TEM-2 by 
several point mutations that are mostly involved in the extension of the substrate range of the enzymes (Collatz et al., 1989; Mabilat \& Courvalin, 1990; Mabilat et al., 1990; Sougakoff et al., 1988b, 1989).

$\beta$-Lactamase TEM-6 was detected in Escherichia coli HB251, which is resistant to ceftazidime and aztreonam but susceptible to other third-generation cephalosporins (Bauernfeind \& Hörl, 1987). The enzyme is characterized by an isoelectric point of 5.9 and the corresponding gene is transferable by conjugation, together with chloramphenicol, kanamycin and sulphonamide resistance determinants, to other $E$. coli strains. DNA-DNA hybridization with a probe specific for TEM-1 indicated that the gene encoding TEM-6, designated blaT-6, is closely related to the structural blaT genes for TEM-type penicillinases (Sougakoff et al., 1988a).

In this study, the molecular characterization of blaT-6 and of its promoter region is presented. We found upstream from blaT-6 a 116 bp DNA element related to insertion sequence IS 1 . The major features of the active hybrid-promoter $\mathrm{P}_{6}$ created by insertion of this DNA fragment have been determined. The distribution of the IS $I$-like element was studied in clinical isolates that produced TEM- 6 or other TEM variants.

\section{Methods}

Strains, plasmids and media. E. coli HB251, harbouring plasmid pIP1844 [Tra ${ }^{+}$, blaT-6 (TEM-6), $\mathrm{Ap}^{r} \mathrm{Cm}^{r} \mathrm{Km}^{\mathrm{r}} \mathrm{Su}^{\mathrm{r}}$, approx. $200 \mathrm{~kb}$ ], and recipient strain $E$. coli $\mathrm{A} 15$, plasmid-free and resistant to nalidixic acid, have been described (Bauernfeind \& Hörl, 1987). E. coli THB251 corresponds to transconjugant A15(pIP1844) and produces a $\beta$ lactamase with an isoelectric point of 5.9 (Bauernfeind \& Hörl, 1987). Plasmids pBR322 (Ap' Tcr, 4.3 kb) (Bolivar et al., 1977) and pKK232-8 $\left(\mathrm{Ap}^{\mathrm{r}}, 4.6 \mathrm{~kb}\right)$ (Brosius, 1984) were from our laboratory collection. E. coli HBI01 (Boyer \& Roulland-Dussoix, 1969) was the host strain for recombinant plasmids. E. coli BM2570 has been previously described (Brisson-Noël et al., 1988). The strains isolated in the Federal Republic of Germany were obtained in an intensive care unit from patients treated with ceftazidime alone or combined with tobramycin (Bauernfeind et al., 1989). E. coli THB82, 87, 91, 102, 103, 107, 114, 136 and 137 are transconjugants derived from these strains by mating with $E$. coli A15 and selecting for ampicillin and nalidixic acid resistance. Clinical isolates resistant to $\beta$-lactams were described previously (Mabilat \& Courvalin, 1990). Strains were grown in brain heart infusion broth and agar (Difco), containing ampicillin at $100 \mu \mathrm{g} \mathrm{ml}^{-1}$ or chloramphenicol at $10 \mu \mathrm{g} \mathrm{m}^{-1}$ when required.

Mating experiments. Donor and recipient strains were mixed in the same ratio and mating was performed on a nitrocellulose filter for $48 \mathrm{~h}$. Transconjugants were selected on agar containing nalidixic acid $\left(50 \mu \mathrm{g} \mathrm{m}^{-1}\right)$ and ampicillin $\left(100 \mu \mathrm{g} \mathrm{ml}^{-1}\right)$.

Determination of $99 \%$ inhibitory concentrations $\left(I C_{99}\right)$ of antibiotics. Concentrations of antibiotics that inhibited $99 \%$ of bacterial growth were determined as described by Chabbert \& Derlot (1983).

Preparation of DNA and nucleic acid techniques. Plasmid pIP1844 DNA was prepared by caesium chloride/ethidium bromide ultracentrifugation as described by Labigne-Roussel et al. (1981). Digestion with restriction endonucleases (Amersham), cloning experiments and electrophoresis in $0.8 \%$ agarose gels were performed as described by Maniatis et al. (1982).

Amplification and sequencing of DNA and computer analysis of sequence data. The polymerase chain reaction (PCR) with oligonucleotides A, B, C, E and $G$ was performed as described by Mabilat $e$ al. (1990), using $25 \mathrm{ng}$ plasmid DNA as a template. PCR with oligonucleotides $\mathrm{F}, \mathrm{J}$ and $\mathrm{K}$ was carried out in a final volume of $100 \mu \mathrm{l}$ containing $10 \mu \mathrm{l}$ of a $1: 1000$ diluted overnight culture lysed by heating at $95^{\circ} \mathrm{C}$ for $3 \mathrm{~min}$. The 35 amplification cycles were performed as follows: annealing at $55^{\circ} \mathrm{C}$ for $1 \mathrm{~min}$, extension step at $72{ }^{\circ} \mathrm{C}$ for $30 \mathrm{~s}$ and denaturation at $94^{\circ} \mathrm{C}$ for $30 \mathrm{~s}$. The Taq DNA polymerase was purchased from PelkinElmer, Cetus Co. PCR-amplified DNA was purified (Maniatis et al., 1982) and sequenced directly with T7 polymerase (Sequenase) using the protocol of Tabor \& Richardson (1987) as described previously (Mabilat et al., 1990). Oligonucleotides A to $G$ used as amplification and/or sequencing primers were described by Mabilat et al. (1990). Amplification primers $\mathbf{J}\left(5^{\prime}\right.$-d $\{$ GGTAATGATACCAACGT $\left.\}-3^{\prime}\right)$ and K (5'-d $\{$ GGTAATGCTGTCAACCT $\left.\}-3^{\prime}\right)$ were also used. DNA sequences were compared using the algorithm of Wilbur \& Lipman (1983).

Nucleic acid hybridization. For Southern hybridization (Southern, 1975), DNA restriction fragments fractionated by agarose gel electrophoresis were transferred to Nytran membranes (Schleicher \& Schuell). Prehybridization and hybridization were carried out at $65^{\circ} \mathrm{C}$ in $6 \times \mathrm{SSC}(1 \times \mathrm{SSC}$ is $0.15 \mathrm{M}-\mathrm{NaCl}, 0.015 \mathrm{M}$-sodium citrate $), 0.5 \%$ sodium dodecyl sulphate and $0.05 \%$ nonfat dry milk (Johnson et al., 1984). Colony hybridization was as described by Grunstein \& Hogness (1975). Probes were labelled with $[\alpha-32$ P]dATP (Amersham) by nicktranslation (Maniatis et al., 1982). The probe specific for blaT genes was a 347 bp fragment internal to blaT -1 obtained by PCR using primers $C$ and $E$ (Fig. I). The IS $/$-specific probe consisted of the $0.5 \mathrm{~kb}$ PstI-Bst NI fragment of plasmid pAT69 (Brisson-Noël et al., 1988).

Enzyme assays and analytical isoelectric focusing. Chloramphenicol acetyltransferase and $\beta$-lactamase activities were assayed using the protocol of Lupski et al. (1984). The isoelectric point of $\beta$-lactamases was determined on polyacrylamide gels by the method of Matthew \& Hedges (1976). The enzymes were revealed with nitrocefin (Glaxo) (Barthélémy et al., 1978).

\section{Results}

Comparative analysis by agarose gel electrophoresis of plasmid DNA from wild strain E. coli HB251 and from transconjugant $E$. coli THB251 (data not shown) indicated that blaT-6 was part of a plasmid, named pIP1844, of about $200 \mathrm{~kb}$. The presence of a blaT gene on pIP1844 was confirmed by DNA-DNA hybridization. The blaT probe specific for TEM-type $\beta$-lactamases hybridized to a $7 \mathrm{~kb}$ BamHI-generated fragment and to EcoRI and HindIII fragments of approximately $12 \mathrm{~kb}$ (data not shown).

\section{Amplification and sequencing of blaT-6 and of its promoter and comparison with blaT genes}

We amplified by PCR (Saiki et al., 1988), using oligonucleotide primers A and B (Mabilat et al., 1990) and plasmid pIP1844 DNA as a template (Fig. 1), a 


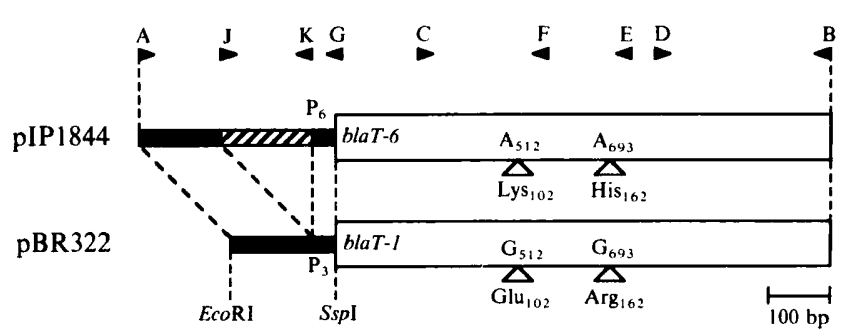

Fig. 1. Strategy for amplification and nucleotide sequencing of blaT-6 and comparison with blaT-1. Heavy line, homologous DNA in pIP1844 (top) and pBR322 (bottom). Hatched line, 116 bp DNA insert upstream from blaT -6 . Open boxes, genes bla T-6 in pIP1844 and blaT-I in pBR322. Letters in the boxes indicate nucleotides at positions 512 and 693. The corresponding amino acids are represented under open triangles. Arg, arginine; Glu, glutamic acid; His, histidine; Lys, lysine. The numbering system is that of Sutcliffe (1978). $P_{6}$ and $P_{3}$, promoters of blaT-6 and blaT-1, respectively. Arrows, primers for amplification and/or sequencing.

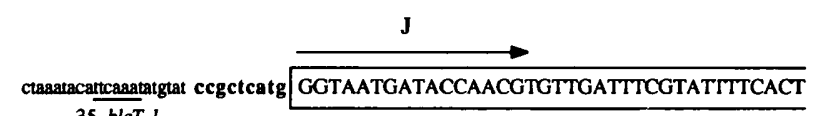
-35 blat -1

GACACCAGGATCATCCTGATGTTACAAGGATTGAATGACTACAGATTAAAATAGTC

\begin{tabular}{|c|c|}
\hline $\mathbf{K}$ & \\
\hline ATCAACAGGTTGACAGCATTACC & $\begin{array}{l}\text { Jecgetcatg agacaataaccctgataaat } \\
-10 \mathrm{blaT}-1\end{array}$ \\
\hline
\end{tabular}

Fig. 2. DNA sequence upstream from blaT-6. The nucleotide sequence of pIP1844 is indicated by lower-case letters. The first nucleotide in the sequence, as presented, corresponds to that at position 130 in blaT-1 (Sutcliffe, 1978). The -35 and -10 regions of the promoter of blaT -1 (Chen \& Clowes, 1984) and the -35 consensus sequence of blaT-6 are underlined. The 116 bp DNA fragment inserted in the promoter region of blaT-6 is represented by boxed upper-case letters. Bold letters represent the 9 bp directly repeated sequences. Arrows, primers J and $\mathrm{K}$ used for amplification.

$1 \cdot 2 \mathrm{~kb}$ DNA fragment including blaT- 6 that was sequenced directly. Substitutions in blaT-6 relative to blaT$l$ encoding TEM-1 are indicated in Fig. 1. The genes differ at positions 512 and 693 , where a transition of $A$ in blaT-6 to $\mathrm{G}$ in blaT-1 had occurred. In blaT-6, mutations $\mathrm{A}_{512}$ and $\mathrm{A}_{693}$ determine a lysine at amino acid number 102 and a histidine at residue 162 instead of glutamic acid and arginine, respectively, in TEM-1. Comparison of sequences upstream from blaT-6 and blaT-1 revealed that the promoter region of blaT-6 differed from that of blaT-1 by insertion of a 116 bp DNA fragment (Fig. 1).

\section{Sequence analysis of the $116 \mathrm{bp}$ DNA fragment inserted into the promoter region of blaT-6}

As shown in Fig. 2, the 116 bp insertion occurred between the -35 and -10 regions of promoter $P_{3}$ of blaT-1, which was consequently disrupted. However, analysis of the sequence indicated that another pro-

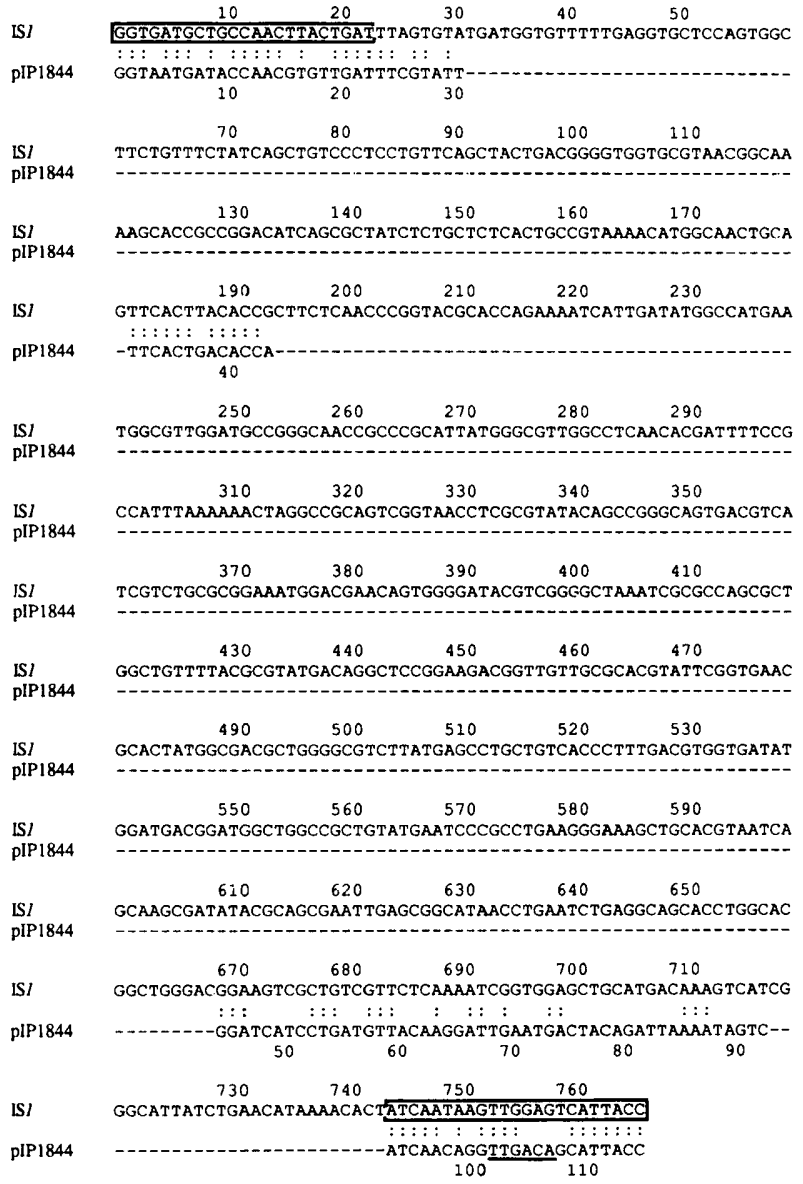

Fig. 3. Sequence comparison between IS $I$ and the $116 \mathrm{bp}$ insert in pIP1844. Identities are indicated by dots. Dashes represent gaps introduced to ensure optimal homology. Numbering begins at the first nucleotide of each sequence. The -35 region of the $116 \mathrm{bp}$ insert (positions 103-108) is underlined. The terminal inverted repeats of ISI are boxed.

moter, designated $P_{6}$, was formed. It is composed of the -10 region of $P_{3}$ and of a -35 TTGACA sequence provided by the right end of the insert. The -10 and -35 sequences of the hybrid promoter of blaT- 6 are separated by 18 nucleotides, a spacing 1 bp longer than that in $\mathrm{P}_{3}$ (Chen \& Clowes, 1984).

Another feature of the DNA sequence upstream from blaT-6 is the presence of a $9 \mathrm{bp}$ sequence (CCGCTCATG) that is directly repeated at the boundary of the insert (Fig. 2). Insertion of IS elements is accompanied by a short (2-12 bp) duplication of target DNA so that the transposed element is flanked by direct repeats (Grindley \& Reed, 1985). It therefore appears that the presence of the $116 \mathrm{bp}$ DNA fragment in the $\beta$ lactamase promoter results from a transposition event. The sequence of the $116 \mathrm{bp}$ DNA fragment was compared with those of known IS elements and homology with ISl (Ohtsubo \& Ohtsubo, 1978) was found (Fig. 3). Segments from bp 1 to 31 and from bp 94 
Table 1. Chloramphenicol resistance and $C A T$ versus $\beta$ lactamase activity (Lupski et al., 1984) in E. coli HB101 harbouring $p K K 232-8$ containing different blaT promoters

\begin{tabular}{|c|c|c|c|c|}
\hline \multirow[b]{2}{*}{ Promoter } & \multicolumn{2}{|c|}{ Nucleotide sequence } & \multirow{2}{*}{$\begin{array}{c}\mathrm{IC}_{99} \text { of } \mathrm{Cm} \\
\left(\mu \mathrm{g} \mathrm{ml}^{-1}\right)\end{array}$} & \multirow{2}{*}{$\begin{array}{c}10^{-3} \times \\
\text { CAT } / \beta \text {-lactamase } \\
\text { activity }\end{array}$} \\
\hline & -35 region & -10 region & & \\
\hline - & - & - & 5 & $<1$ \\
\hline$P_{3}$ & TTCAAA & GACAAT & 80 & 33 \\
\hline$P_{6}$ & TTGACA & GACAAT & 800 & 306 \\
\hline
\end{tabular}

to 116 of the insert shared $71 \%$ and $74 \%$ similarity with the left and right ends of IS 1 , respectively. Another region, nucleotides $32-44$, was highly similar $(85 \%)$ to the 182-194 bp region in IS 1 . The degree of similarity between nucleotides 45-93 of the insert and 670-718 of ISI was lower $(37 \%)$.

\section{Analysis of the strength of hybrid promoter $P_{6}$ of blaT-6}

As already mentioned, the IS 1 -like element contributed a -35 sequence, TTGACA, to $P_{6}$ (Fig. 2). This is equivalent to the consensus sequence for $E$. coli promoters (Hawley et al., 1983). The hexanucleotide TTCAAA in the -35 region of $P_{3}$ is less related to the consensus. Since the -35 region is known to play an important role in promoter strength (Moran et al., 1982), we compared the level of expression of $\mathrm{P}_{6}$ of blaT-6 and of $P_{3}$ of blaT- 1 . The $0.34 \mathrm{~kb}$ DNA fragment including $\mathrm{P}_{6}$ of pIP1844 that was obtained after amplification with oligonucleotides $\mathrm{A}$ and $\mathrm{G}$ and digestion with $S s p \mathrm{I}$ and the $0.19 \mathrm{~kb} E c o R I-S s p I$ fragment of pBR322 that contains $\mathrm{P}_{3}$ (Fig. 1) were inserted into the Smal site of the promoter-probe plasmid pKK232-8 (Brosius, 1984).
In this replicon, the $S m a$ I site is located upstream from a promoterless chloramphenicol acetyltransferase (CAT) gene and expression of the enzyme is dependent upon transcription originating in the inserts. The promoter strength was expressed by the ratio of CAT activity to $\beta$ lactamase activity (Lupski, 1984) and was also assessed by the level of chloramphenicol resistance of the host (Table 1). When $P_{6}$ was fused to the CAT gene, there was a 10 -fold higher CAT $/ \beta$-lactamase ratio and chloramphenicol resistance level as compared to the fusion with $\mathrm{P}_{3}$.

\section{Distribution of the ISl-like element among Enterobacteriaceae}

$\beta$-Lactamase TEM-6 was first detected in two $E$. coli strains isolated in the Federal Republic of Germany (Bauernfeind \& Hörl, 1987). Since 1987, outbreaks of infections due to enterobacteria resistant to ceftazidime have been observed in this country (Bauernfeind $e t$ al., 1989). Nine transconjugants in E. coli A15 expressing resistance to ceftazidime were chosen because they were shown to produce TEM-6, as judged by analytical isoelectric focusing (data not shown). Since the study of blaT-6 from pIP1844 showed that an IS1-like element was inserted into the promoter region for the gene, we searched, by DNA amplification, for the 116 bp insert in the promoter region of blaT- 6 in the transconjugants. Oligonucleotides $\mathbf{J}$ and $\mathrm{K}$ (Fig. 2) will only amplify the IS 1 -like element, whereas primers $\mathrm{J}$ and $\mathrm{F}$ (Fig. 1) allow amplification of a $525 \mathrm{bp}$ fragment only when the $116 \mathrm{bp}$ insert is present in the promoter region. Resolution of amplified DNA by agarose gel electrophoresis (Fig. 4) showed that the ISI-like element was present in the promoter region of the gene for TEM-6 in each transconjugant.

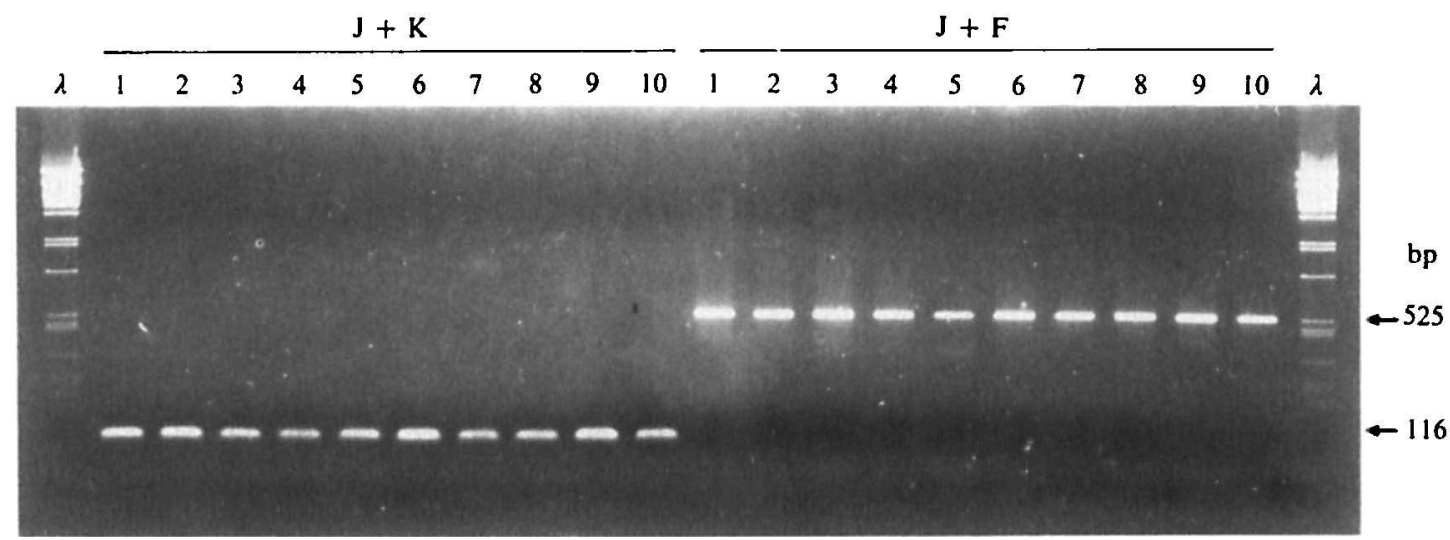

Fig. 4. Agarose gel electrophoresis of DNA fragments obtained by PCR with oligonucleotides $J$ and $K$ (left) or J and F (right). Lanes: 1, THB251; 2, THB82; 3, THB87; 4, THB91; 5, THB102; 6, THB103; 7, THB107; 8, THB114; 9, THB136; 10, THB137. PstI-generated fragments of bacteriophage $\lambda$ were used as molecular size standards. The size of the amplified fragments is indicated on the right. No amplification product was observed when DNA of $E$. coli BM 2570 harbouring IS 1 was used as a template (data not shown). 
Table 2. Distribution of the IS1-like element in clinical isolates resistant to $\beta$-lactam antibiotics

\begin{tabular}{|c|c|c|c|c|}
\hline \multirow[b]{3}{*}{ Species } & \multicolumn{4}{|c|}{ No. of strains } \\
\hline & \multicolumn{2}{|c|}{ Producing TEM $\beta$-lactamases* } & \multicolumn{2}{|c|}{ Producing non-TEM $\beta$-lactamases } \\
\hline & + & - & + & - \\
\hline Citrobacter freundii & & 3 & 1 & \\
\hline Enterobacter cloacae & 5 & 8 & 3 & 2 \\
\hline Escherichia coli & 1 & 45 & 2 & 6 \\
\hline Klebsiella pneumoniae & 93 & 43 & 16 & 12 \\
\hline K. oxytoca & 4 & 2 & 3 & \\
\hline K. ozaenae & & & 2 & \\
\hline Proteus spp. & & 2 & & \\
\hline Serratia marcescens & & 6 & & 1 \\
\hline $\begin{array}{l}\text { Salmonella typhimurium } \\
\text { and non-typable Salmonella }\end{array}$ & & & 6 & \\
\hline
\end{tabular}

Colony hybridization using the $116 \mathrm{bp}$ fragment amplified with primers $\mathbf{J}$ and $\mathrm{K}$ as a probe was used to study the distribution of the IS 1 -like element in $266 \beta$ lactam-resistant clinical isolates that originated from various hospitals in five countries (Table 2). The probe did not hybridize to DNA from $E$. coli BM2570, which harbours ISI (data not shown), indicating that it is specific for the IS 1 -like element. Among the strains tested, 218 produced TEM-type enzymes whereas the remainder (48) encoded non-TEM $\beta$-lactamases (Mabilat \& Courvalin, 1990). The IS 1 -like element was found in $103(47 \%)$ isolates harbouring TEM variants and in 27 $(56 \%)$ strains producing non-TEM enzymes (Table 2 ). In TEM-producing strains, homology with the IS1-like probe was detected in $93(68 \%) \mathrm{K}$. pneumoniae isolates. One of $46 E$. coli isolates hybridized with the probe and the IS 1 -like element was not found in Citrobacter freundii, Proteus spp., Salmonella typhimurium and Serratia marcescens. Among the isolates producing non-TEM $\beta$ lactamases, $16(57 \%) \mathrm{K}$. pneumoniae strains hybridized with the probe. The IS 1 -like element was also found in $E$. coli, Enterobacter cloacae, $K$. oxytoca and $K$. ozaenae. The only strain of $C$. freundii tested hybridized with the probe whereas that of $S$. marcescens did not.

\section{Discussion}

E. coli HB251, a strain that is highly resistant to ceftazidime and aztreonam, was isolated from a patient treated with ceftazidime. Cephalosporin resistance in this strain is due to production of the extended-spectrum $\beta$-lactamase TEM- 6 encoded by the approximately $200 \mathrm{~kb}$ plasmid pIP1844.

TEM-type $\beta$-lactamases that hydrolyse third-generation cephalosporins differ from penicillinases TEM-1 and TEM-2 by a few amino acid substitutions (Collatz et al., 1989; Mabilat \& Courvalin, 1990; Mabilat et al., 1990; Sougakoff et al., 1988 b, 1989). Determination of the sequence of blaT-6 encoding TEM-6 in E. coli HB251 showed that the resistance gene differed from blaT-I specifying TEM-1 by two point mutations (Fig. 1). The nucleotide substitutions correspond, in the primary structure of TEM enzymes, to a lysine and a histidine in TEM-6 in place of a glutamic acid and an arginine in TEM-1 at positions 102 and 162, respectively (Fig. 1). Lysine 102 has been previously detected in extendedspectrum $\beta$-lactamases TEM-3, -4 and -9 , whereas the Arg to His substitution at amino acid position 162 has not previously been reported in a TEM variant of clinical origin. This histidine, however, was the only change in an extended-spectrum variant hydrolysing ceftazidime and aztreonam which was obtained by ultraviolet mutagenesis of the structural gene for a TEM-type penicillinase (W. Sougakoff, S. Goussard \& P. Courvalin, unpublished result). Since lysine 102 is known to be implicated in the hydrolysis of ceftazidime and aztreonam by TEM variants (Sougakoff et al., 1988b) the high-level resistance of strains producing TEM-6 (Philippon et al., 1989) may therefore reflect a combination of the effects of each substitution. A similar phenomenon has already been proposed to account for the high catalytic activity towards ceftazidime of the extendedspectrum $\beta$-lactamase TEM-9 (Mabilat et al., 1990). This enzyme also differs from TEM-1 by two amino acid substitutions, a lysine at position 102 (as in TEM-6) and a serine at position 162 which confers resistance to ceftazidime in TEM-7 (Collatz et al., 1989). The location of residues 102 and 162 in the three-dimensional structure of the class A $\beta$-lactamase of Staphylococcus aureus PC1 (Herzberg \& Moult, 1987) indicates that these amino acids could be part of the substrate-binding 
site (Sougakoff et al., 1989); however, the mechanism by which substitutions in these positions expand the substrate range of the enzyme is still unknown.

Sequence determination of blaT-6 and of its promoter region showed that a 116 bp insertion occurred between the -35 recognition site and the -10 Pribnow box of promoter $\mathrm{P}_{3}$ of the blaT-1 gene (Fig. 2). Analysis of the sequence of the insert (Fig. 3) suggested that it is derived from the $768 \mathrm{bp}$ insertion sequence IS $/$ by two types of events: (i) three internal deletions and (ii) nucleotide substitutions in the remaining portions where the overall similarity was $59 \%$. Nucleotide similarity was highest in the terminal inverted repeats of the two elements (Fig. 3). Transposition of IS $I$ results in the duplication of $9 \mathrm{bp}$ of the target (Prentki et al., 1986). Since a 9 bp sequence is repeated directly at the ends of the IS 1 -like element, it is likely that the presence of the 116 bp DNA fragment is the result of a transposition event. The IS-related insert does not contain the central region of IS 1 coding for the transposase. Therefore, deletions in the $116 \mathrm{bp}$ insert occurred after insertion of the element or, alternatively, insertion had to be promoted by transposition functions provided in trans by another IS element such as IS 1 that is common in $E$. coli. In fact, nucleotide sequences homologous to IS $/$ were detected in PIP1844 DNA by hybridization using an IS $l$-specific probe (data not shown).

Insertion of the IS 1 -like element between the -35 and -10 sequences of the $\mathrm{P}_{3}$ promoter of blaT-1 did not abolish resistance to $\beta$-lactam antibiotics. Sequence analysis at the junction of the $116 \mathrm{bp}$ fragment and of the region upstream from blaT-6 showed that insertion generated a hybrid promoter $P_{6}$ in which the TTCAAA -35 recognition site of $P_{3}$ was replaced by the -35 sequence TTGACA located at the right end of the element (Fig. 2), which is identical to the consensus sequence for $E$. coli promoters. The distance between the -10 and -35 regions in $P_{6}$ is 18 bp and corresponds to the preferred spacer ( 17 or $18 \mathrm{bp}$ ) for an E. coli promoter (Moran et al., 1982). Comparison of the strength of the promoters and of the antibiotic resistance levels of the hosts (Table 1) indicated that the hybrid promoter of TEM-6 is 10 times stronger than $P_{3}$ of blaT-1. It therefore appears that acquisition of both a strong promoter and point mutations in the structural gene contribute to the ability of TEM-6-producing bacteria to resist the lethal effect of third-generation cephalosporins. The fact that the strong $\mathrm{P}_{\mathrm{a}} \mathrm{P}_{\mathrm{b}}$ promoter, which is 10 times more efficient than $\mathrm{P}_{3}$ (Chen \& Clowes, 1984), has been found upstream from the structural genes for TEM-3, $-4,-5,-7$ and -9 (Collatz et al., 1989; Mabilat et al., 1990; Sougakoff et al., 1988b, 1989) is consistent with this notion.

Insertion of IS 1 into the promoter $P_{3}$ of blaT-1 in plasmid pBR322 has been reported (Prentki et al., 1986). The insertion was at the same position as that of the ISIlike element upstream in blaT-6 and resulted in the formation of an active hybrid promoter consisting of the -10 region from $P_{3}$ and a -35 TTGGCA region provided by the end of IS 1 . However, gene expression from the resulting hybrid promoter was less efficient than that from $P_{3}$. An explanation for this difference could be that the -35 region of the 'IS 1 -hybrid promoter' has a poorer match to the canonical -35 consensus than that in $P_{6}$. Alternatively, features of the regions upstream from the -35 sequences in IS 1 and in the IS 1 -like element might be important for promoter recognition by the RNA polymerase (Moran et al., 1982; Prentki et al., 1986).

The IS 1 -like element was detected by PCR, using two oligonucleotides specific for the ends of the insert (Fig. 2 ), in transconjugants derived from clinical isolates expressing resistance to ceftazidime and aztreonam by production of TEM-6. Using another pair of primers, $\mathbf{J}$ and $F$ (Fig. 1), we found that insertion of the element occurred in the promoter region of blaT-6 in the nine strains tested (Fig. 4). It is therefore tempting to speculate that presence of the IS 1 -like element into the $\beta$ lactamase promoter, which contributes to the survival of the host in the presence of third-generation cephalosporins, was selected by extensive use of these drugs in clinical settings.

Study of the distribution of the IS 1 -like element in enterobacteria of various origins by DNA-DNA hybridization indicated the presence of DNA sequences related to the insert in $47 \%$ of the clinical isolates producing a TEM-type enzyme and in $56 \%$ of the strains producing non-TEM $\beta$-lactamases (Table 2). The IS 1 like element therefore appears to be widespread in members of the family Enterobacteriaceae and not exclusively linked to blaT-6.

We thank A. Andremont, M. Archambaud, R. Bismuth, E. Borderon, P. Bourlioux, A. Bouvet, Y. Brun, D. Coullioud, F. Delisle, H. Drugeon, J. Duval, J. P. Flandrois, J. Fleurette, H. Gabrielle, J. P. Gayral, L. Gutmann, A. M. Harris, V. Jarlier, A. Kazmierczak, P. Lagrange, T. Lambert, P. Legrand, J. Lemozy, D. Lesage, J. L. Martel, Y. Michel-Briand, N. Moatti, C. Morel, M. H. Nicolas, A. Philippon, I. Phillips, P. Roy, J. Salauze, A. Sedallian, J. Sirot, J. C. Torlotin, G. Vedel and G. Verschraegen for the gift of strains. C. Mabilat was a recipient of fellowship 324/86 from Convention Industrielle de Formation par la Recherche (CIFRE) and W. Sougakoff was a recipient of fellowships from the Ministère de la Recherche et de la Technologie and from the Institut Beecham.

\section{References}

Barthélémy, M., Guionie, M. \& Labia, R. (1978). $\beta$-Lactamases: determination of their isoelectric points. Antimicrobial Agents and Chemotherapy 13, 695-698. 
Barthélémy, M., Péduzzi, J., Ben Yaghlane, H. \& Labia, R. (1988). Single amino acid substitution between SHV-1 $\beta$-lactamase and cefotaxime-hydrolyzing SHV-2 enzyme. FEBS Letters 231, 217-220.

Bauernfeind, A. \& HörL, G. (1987). Novel R-factor borne $\beta$ lactamase of Escherichia coli conferring resistance to cephalosporins. Infection 15, 257-259.

Bauernfeind, A., Kluučar, S. V., Pritzbuer, E. \& Medeiros, A. (1989). Epidemiology of resistance due to TEM-6 $\beta$-lactamase in enterobacteriaceae in intensive care patients. In Abstracts of the 4th European Congress of Clinical Microbiology, abstract no. 1125.

Bolivar, F., Rodriguez, R. L., Betlach, M. C. \& Boyer, H. W. (1977). Construction and characterization of new cloning vehicles. I. Ampicillin-resistant derivatives of the plasmid pMB9. Gene 2, 75-93.

BOYER, H. W. \& Roulland-Dussorx, D. (1969). A complementation analysis of the restriction and modification of DNA in Escherichia coli. Journal of Molecular Biology 41, 459-472.

Brisson-NoËL, A., ARTHUR, M. \& CoURVAlin, P. (1988). Evidence for natural gene transfer from gram-positive cocci to Escherichia coli. Journal of Bacteriology 170, 1739-1745.

Brosius, J. (1984). Plasmid vector for the selection of promoters. Gene 27, 151-160.

Chabbert, Y. A. \& Derlot, E. (1983). Comparative activity of cefotetan on Escherichia coli $\mathrm{K} 12$ possessing plasmid-mediated $\beta$ lactamases. Journal of Antimicrobial Chemotherapy 11, 159-167.

Chen, S. T. \& Clowes, R. C. (1984). Two improved promoter sequences for the $\beta$-lactamase expression arising from a single basepair substitution. Nucleic Acids Research 12, 3219-3234.

Collatz, E., Tran Van Nhieu, G., Billot-Klein, D., Williamson, R. \& Gutmann, L. (1989). Substitution of serine for arginine in position 162 of TEM-type $\beta$-lactamases extends the substrate profile of mutant enzymes, TEM-7 and TEM-101, to ceftazidime and aztreonam. Gene 78, 349-354.

GRINDLEY, N. D. \& REED, R. R. (1985). Transpositional recombination in prokaryotes. Annual Review of Biochemistry 54, 863-896.

GRUNSTEIN, M. \& HogNESS, D. (1975). Colony hybridization: a method for the isolation of cloned DNAs that contain a specific gene. Proceedings of the National Academy of Sciences of the United States of America 72, 3961-3965.

HAWLEY, D. K. \& MCCLURE, D. W. (1983). Compilation and analysis of Escherichia coli promoter DNA sequence. Nucleic Acids Research 11, 2237-2255.

Herzberg, O. \& Moult, J. (1987). Bacterial resistance to $\beta$-lactam antibiotics: crystal structure of $\beta$-lactamase from Staphylococcus aureus $\mathrm{PCl}$ at $2.5 \AA$ resolution. Science 236, 694-701.

Johnson, D. A., Sportsman, J. \& Elder, J. (1984). Improved technique utilizing nonfat dry milk for analysis of proteins and nucleic acids transferred to nitrocellulose. Gene Analysis Techniques 1, 3-8.

Kliebe, C., Nies, B. A., Meyer, J. F., Tolxdorff-Neutzling, R. M. \& WIEDEMANN, B. (1985). Evolution of plasmid-coded resistance to broad-spectrum cephalosporins. Antimicrobial Agents and Chemotherapy 28, 302-307.

Knothe, H., Shah, P., Krcméry, V., Antal, M. \& Mitsuhashi, S. (1983). Transferable resistance to cefotaxime, cefoxitin, cefamandole and cefuroxime in clinical isolates of Klebsiella pneumoniae and Serratia marcescens. Infection 11, 315-317.

Labigne-Roussel, A., Gerbaud, G. \& Courvalin, P. (1981). Translocation of sequences encoding antibiotic resistance from the chromosome to a receptor plasmid in Salmonella ordonez. Molecular and General Genetics 182, 390-408.

LUPSKI, J. R., RuIz, A. A. \& Godson, G. N. (1984). Promotion, termination, and anti-termination in the rps $U-d n a G-r p o D$ macromolecular synthesis operon of E. coli K-12. Molecular and General Genetics 195, 391-401.

Mabilat, C. \& Courvalin, P. (1990). Development of 'oligotyping' for characterization and molecular epidemiology of TEM $\beta$-lactamases in Enterobacteriaceae. Antimicrobial Agents and Chemotherapy 34, 2210-2216.

Mabilat, C., Goussard, S., Sougakoff, W., Spencer, R. C. \& Courvalin, P. (1990). Direct sequencing of the amplified structural gene and promoter for the extended-broad-spectrum $\beta$-lactamase TEM-9 (RHH-1) of Klebsiella pneumoniae. Plasmid 23, 27-34.
Maniatis, T., Fritsch, E. F. \& Sambrook, J. (1982). Molecular Cloning. A Laboratory Manual. Cold Spring Harbor, NY: Cold Spring Harbor Laboratory.

MATTHEW, M. \& HedGes, R. W. (1976). Analytical isoelectric focusing of $\mathbf{R}$ factor-determined $\beta$-lactamases: correlation with plasmid compatibility. Journal of Bacteriology 125, 713-718.

Medeiros, A. A. (1989). Plasmid-determined $\beta$-lactamases. In Microbial Resistance to Drugs, pp. 101-127. Edited by L. E. Bryan. Berlin: Springer-Verlag.

Moran, C. P., Lang, N., LeGrice, S. F., Lee, G., Stephens, M., Sonenshein, A. L., Pero, J. \& Losick, R. (1982). Nucleotide sequences that signal the initiation of transcription and translation in Bacillus subtilis. Molecular and General Genetics 186, 339-346.

Онтsubo, Е. \& OHтsubo, H. (1978). Nucleotide sequence of an insertion element IS1. Proceedings of the National Academy of Sciences of the United States of America 75, 615-619.

Paul, G. C., Gerbaud, G., Buré, A., Philippon, A. M., Pangon, B. \& Courvalin, P. (1989). TEM-4, a new plasmid-mediated $\beta$-lactamase that hydrolyzes broad-spectrum cephalosporins in a clinical isolate of Escherichia coli. Antimicrobial Agents and Chemotherapy 33, 19581963.

Petit, A., Sirot, D. L., Chanal, C. M., Sirot, J. L., Labia, R., Gerbaud, G. \& Cluzel, R. A. (1988). Novel plasmid-mediated $\beta$ lactamase in clinical isolates of Klebsiella pneumoniae more resistant to ceftazidime than to other broad-spectrum cephalosporins. Antimicrobial Agents and Chemotherapy 32, 626-630.

Philippon, A., LABIA, R. \& JACOBY, G. (1989). Extended-spectrum $\beta$ lactamases. Antimicrobial Agents and Chemotherapy 33, 11311136.

Prentiki, P., Teter, B., Chandler, M. \& Galas, D. J. (1986) Functional promoters created by the insertion of transposable element IS $I$. Journal of Molecular Biology 191, 383-393.

Saiki, R. K., Gelfand, D. H., Stoffel, S., Scharf, S. J., Higuchi, R., HoRN, G. T., Mullis, K. B. \& ERLICH, H. A. (1988). Primer directed enzymatic amplification of DNA with a thermostable DNA polymerase. Science $239,487-494$.

Sirot, D., Sirot, J., Labia, R., Morand, R., Courvalin, P., Darfeuille-Michaud, A., Perroux, R. \& Cluzel, R. (1987). Transferable resistance to third-generation cephalosporins in clinical isolates of Klebsiella pneumoniae: identification of CTX-1, a novel $\beta$-lactamase. Journal of Antimicrobial Chemotherapy 20, 323334.

Sougakoff, W., Goussard, S. \& Courvalin, P. (1988a). Plasmidmediated resistance to third-generation cephalosporins caused by point mutations in TEM-type penicillinase genes. Reviews of Infectious Diseases 10, 879-884.

SougakofF, W., Goussard, S. \& Courvalin, P. (1988b). The TEM-3 $\beta$-lactamase, which hydrolyzes broad-spectrum cephalosporins, is derived from the TEM-2 penicillinase by two amino acid substitutions. FEMS Letters 56, 343-348.

Sougakoff, W., Petit, A., Goussard, S., Sirot, D., Buré, A. \& Courvalin, P. (1989). Characterization of the plasmid genes blaT-4 and $b l a T-5$ which encode the broad-spectrum $\beta$-lactamases TEM-4 and TEM-5 in Enterobacteriaceae. Gene 78, 339-348.

SOUTHERN, E. (1975). Detection of specific sequences among DNA fragments separated by gel electrophoresis. Journal of Molecular Biology 98, 503-517.

Spencer, R. C., Wheat, P. F., Winstanley, P. G., Cox, D. M. \& PLested, S. J. (1987). Novel $\beta$-lactamase in a clinical isolate of Klebsiella pneumoniae conferring unusual resistance to $\beta$-lactam antibiotics. Journal of Antimicrobial Chemotherapy 20, 919-927.

SutCliffe, J. G. (1978). Nucleotide sequence of the ampicillin resistance gene of Escherichia coli plasmid pBR322. Proceedings of the National Academy of Sciences of the United States of America 75, 3737-3741.

TABOR, S. \& RICHARDSON, C. C. (1987). DNA sequence analysis with a modified bacteriophage T7 DNA polymerase. Proceedings of the National Academy of Sciences of the United States of America 84, 4767-4771.

WILBUR, W. J. \& LIPMAN, D. J. (1983). Rapid similarity searches of nucleic acid and protein data banks. Proceedings of the National Academy of Sciences of the United States of America 80, 726-730. 